\title{
IMPLEMENTASI PRINSIP AMAR MAKRUF NAHI MUNKAR SEBAGAI ETIKA POLITIK ISLAM
}

\section{BADRUL JIHAD}

Universitas Al-Azhar Kairo

badruljihad10@gmail.com

\begin{abstract}
This article is aimed to discuss the principle of Amar Makruf Nahi Munkar (enjoining what is right and forbidding what is wrong) in relation to Islamic political ethics. This principle is actually one of the main foundations of Islamic teaching that Allah has commanded fellow Muslims to implement. In order to achieve a strong and civilized Muslim society, a principle is needed that holds each individual together in exercising goodness and shunning evil in order to achieve the common good. In this case, Amar Makruf Nahi Munkar is the principle offered by Islam in building such a strong and civilized society.
\end{abstract}

Keywords : Amar Makruf Nahi Munkar, Islamic political ethics

\section{Abstrak}

Artikel ini bertujuan untuk membahas prinsip Amar Makruf Nahi Munkar dalam kaitannya dengan etika politik Islam. Prinsip ini sebenarnya merupakan salah satu landasan utama ajaran Islam yang Allah perintahkan kepada sesama muslim untuk dilaksanakan. Untuk mewujudkan masyarakat muslim yang kuat dan beradab, diperlukan prinsip yang menyatukan setiap individu dalam melakukan kebaikan dan menjauhi keburukan untuk mencapai kebaikan bersama. Dalam hal ini, Amar Makruf Nahi Munkar adalah prinsip yang ditawarkan Islam dalam membangun masyarakat yang kuat dan beradab.

\section{A. Pendahuluan}

Sejak kemunculannya di Jazirah Arab pada abad ke-7 silam, Islam telah mempromosikan ajaran-ajarannya ke seluruh umat 
manusia agar mereka senantiasa memperoleh kejayaan di dunia dan keselamatan di akhirat. Ajaran-ajaran tersebut tertuang dalam bentuk aturan-aturan formal dan nonformal yang mencakup berbagai lini kehidupan manusia, baik yang berkaitan dengan hubungan manusia dengan dirinya sendiri, keluarga, kelompok/komunitas, bahkan negara; baik dalam aspek pendidikan, sosial, ekonomi, juga politik.

Aspek politik adalah salah satu di antara aspek-aspek yang diatur oleh Islam dengan cara yang tidak formal-spesifik; misalnya ia tidak mengatur hal-hal terkait bentuk negara, pembagian kekuasaan, batas wewenang, dan sistem pemilihan kepala negara. Namun bukan berarti jika Islam tidak mengatur aspek politik secara formal maka ia dianggap sebagai hal yang superfisial dan tidak penting. Sebaliknya, Islam memerhatikan aspek politik bukan dari aturan formal, melainkan dari aturan nonformal berupa nilai-nilai universal yang terdapat dalam ayat-ayat Alquran dan Hadis. Hal tersebut demikian karena permasalahan politik adalah satu di antara urusan-urusan keduniaan (al-umūr al-dunyawiyyah) yang aturannya diserahkan kepada manusia sendiri, sebab berdasarkan hadis Nabi Muhammad, manusialah yang lebih tahu tentang urusan-urusan keduniaan mereka. ${ }^{1}$

Kebebasan manusia untuk merumuskan aturan mengenai urusan-urusan perpolitikan dapat dilihat sebagai bentuk pemuliaan

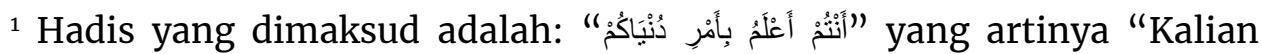
lebih mengetahui tentang perkara keduniaan kalian." Lihat Muhyiddin bin Syaraf al-Nawawi, Shahih Muslim bi Syarh al-Nawawi, (Kairo: Syarikah al-Quds, 2016), hadis no. 2363. 
sekaligus pembebanan Allah terhadap manusia. Dikatakan pemuliaan, sebab jika sistem politik akan diatur secara statis dan eksklusif maka akan memberatkan manusia untuk menjalaninya, sedangkan mereka memiliki situasi dan kondisi yang terus berubah-ubah dan memerlukan aturan partikular yang juga berubah-ubah. ${ }^{2}$ Dikatakan pembebanan sebab manusia dituntut untuk menciptakan suatu sistem politik berkeadilan yang menjamin kelangsungan masyarakatnya, terpenuhinya hak-hak mereka, serta terjaganya mereka dalam kebaikan dan ketaatan pada Allah; hal ini adalah beban yang cukup berat untuk diemban (namun harus dilakukan) oleh manusia. $^{3}$

Dalam memberikan mandat untuk merumuskan aturanaturan partikular tersebut, Islam tetap menggariskan prinsipprinsip dan nilai-nilai universal yang harus dipatuhi sebagai acuan. Prinsip-prinsip ini sebagaimana termaktub dalam Alquran seperti keadilan (al-' $a d l)^{4}$, musyawarah (al-musyawwarah/syūrā $)^{5}$, dan Amar Makruf Nahi Munkar (al-amr bi al-ma'rūf wa al-nahy 'an almunkar). ${ }^{6}$ Keadilan dapat dianggap sebagai tujuan politik, yaitu keadaan dimana tiap warga negara akan mendapat hak-hak dasar mereka dengan adil. Musyawarah berperan sebagai sistem dan tata cara dalam merumuskan aturan-aturan perundang-undangan. Sedangkan Amar Makruf Nahi Munkar akan berperan sebagai etika

${ }^{2}$ Ahmad Syafii Maarif, "Sistem Khilafah dalam Tradisi Islam", TitikTemu, vol. 1, no. 2, Januari-Juni 2009, hlm. 73-74.

3 Ibid., hlm. 83-84

${ }^{4}$ Lihat misalnya QS. Al-Nisa': 58.

${ }^{5}$ Lihat misalnya QS. Ali Imran: 159.

${ }^{6}$ Lihat misalnya QS. Ali Imran: 104. 
dasar dalam sistem politik suatu negara yang akan diimplementasikan baik oleh pemerintah maupun masyarakat.

Amar Makruf Nahi Munkar adalah ajaran dasar agama yang diauki kewajibannya oleh semua aliran dan mazhab keagamaan yang ada. Bahkan aliran Muktazilah sendiri memiliki Lima Fundamen (al-Ushūl al-Khamsah) yang merupakan inti ajaran Islam menurut mereka, yaitu tauhid (al-tauhìd), keadilan (al-'adl), janjijanji (al-wa'd wa al-wa'ìd), tempat antara dua tempat (al-manzilah baina al-manzilatain), dan yang terakhir Amar Makruf Nahi Munkar. Walaupun fundamen-fundamen tersebut bersifat teologis, namun sudah pasti akan berdampak besar dalam urusan-urusan sosial-politik suatu masyarakat. Dengan Amar Makruf Nahi Munkar, ditambah konsep kebebasan kehendak (hurriyyah alirādah) yang menjadi cirinya, ajaran Muktazilah ini dapat terimplementasi dalam bentuk hidupnya budaya saling mengkritik secara konstruktif antara masyarakat dan pemerintah.

Bukan hanya Muktazilah, namun Ahlussunnah wal Jamaah, Syiah, Wahabi, dan semua kelompok-kelompok Islam yang ada juga menganggap Amar Makruf Nahi Munkar adalah fundamen agama walaupun tidak dalam bentuk kumpulan konsep sebagaimana dalam al-Ushul al-Khamsah milik Muktazilah. Para ulama dari berbagai kelompok tersebut telah membahas urgensitas Amar Makruf Nahi Munkar sebagai sebuah prinsip agama. Di antara ulama klasik yang membahas hal tersebut adalah Ibnu Taimiyah (w. 1328) dalam bukunya Al-Amr bi al-Ma'rūf wa al-Nahy 'an al- 
Munkar, dan juga banyak buku-buku lain yang serupa karya ulama kontemporer.

Namun interpretasi dominan terhadap prinsip Amar Makruf Nahi Munkar adalah bahwa ia hanyalah prinsip yang berlaku dalam aspek ibadah murni dan halal-haram belaka. Dalam interpretasi eksklusif seperti ini, para individu-individu Muslim dituntut untuk selalu memberi nasihat dan peringatan kepada sesama Muslim dalam beribadah dan bermuamalah bersama orang lain. Mengingatkan saudara Muslim untuk tetap salat tepat waktu, dan menegurnya jika ia berbohong atau berbuat curang dalam berjual beli, adalah contoh dari interpretasi ini.

Tak dapat disangkal bahwa interpretasi ini adalah benar belaka, sebab memang begitulah cermiman prinsip Amar Makruf Nahi Munkar jika diterapkan. Namun prinsip ini sebenarnya memiliki interpretasi yang lebih luas dari hanya sekadar ibadah murni dan halal-haram, misalnya interpretasi etis dalam kaitannya dengan aspek politik. Interpretasi ini berarti bahwa Amar Makruf Nahi Munkar adalah etika politik yang ditawarkan Islam dalam membentuk suatu masyarakat yang kuat dan beradab. Dalam tataran ini, Amar Makruf Nahi Munkar telah memiliki makna yang mencakup urusan-urusan keduniaan, namun ia tetap bersifat religius.

Etika politik (political ethics), sebagai sudut pandang baru dalam memandang prinsip Amar Makruf Nahi Munkar, dapat diartikan sebagai pedoman manusia dalam menjalankan peran-peran politiknya. Pada dasarnya, etika adalah salah satu bagian dari Fil- 
safat yang langsung mempertanyakan praksis manusia, yakni kewajiban dan tanggung jawabnya sebagai manusia. Politik dan etika sesungguhnya adalah dua hal yang berbeda; politik adalah dunia kekuasaan murni yang diatur dengan asumsi-asumsi kebijakan, sedangkan etika adalah dunia prinsip murni yang diatur oleh imperatif moral. Namun demikian, penggabungan etika dalam politik adalah sesuatu yang urgen karena ia akan mengarahkan manusia pada hidup yang baik dan bersama, dalam rangka memperluas lingkup kebebasan dan membangun institusi-institusi yang adil. ${ }^{7}$

Disebabkan karena manusia sebagai makhluk sosial selalu hidup bersama orang lain dalam masyarakat, dalam tatanan masyarakat terdapat etika sosial. Etika sosial ini membahas normanorma yang seharusnya menentukan sikap dan tindakan dalam hubungan antar manusia. Termasuk dalam wilayah etika sosial ini adalah etika politik, atau filsafat moral mengenai dimensi politik manusia. ${ }^{8}$ Tak dapat diragukan bahwa agama memiliki sumbangsih tersendiri dalam memberikan pandangan terkait etika atau moral. Dalam Islam, penggalian yang dalam akan mengantarkan pada penemuan beragam etika yang berkaitan dengan segala aspek kehidupan manusia, tidak terkecuali aspek politik. Alquran sebagai sumber primer ajaran Islam selain berisi ajaran-ajaran ketuhanan (ilahiyyat), kenabian (nubuwwat), dan eskatologi (sam'iyyat), ia juga berisi pandangan-pandangan terkait etika dan moral. Di bawah ini hlm. 55 dan 59.

${ }^{7}$ Eko Handoyo, dkk, Etika Politik, (Semarang: Widya Karya Press, 2016),

${ }^{8}$ Ibid., hlm. 55-59. 
akan dibahas secara spesifik mengenai prinsip Amar Makruf Nahi Munkar yang merupakan salah satu prinsip keislaman yang dapat berperan sebagai etika politik.

\section{B. Metodologi}

Artikel ini menggunakan pendekatan kualitatif yang bertujuan untuk menganalisis dan mendeskripsikan prinsip Amar Makruf Nahi Munkar dalam kaitannya dengan etika politik Islam. Sebagai metode pengumpulan data, artikel ini menggunakan studi kepustakaan (library research), yaitu dengan mengumpulkan datadata terkait tema yang sedang dibahas dari sumber-sumber berupa buku maupun jurnal. Dalam artikel ini, penulis mencantumkan empat sub-poin yang akan mendukung tujuan dibuatnya artikel ini sebagaimana tertera di judul, empat sub-poin itu adalah: (1) Telaah Singkat Prinsip Amar Makruf Nahi Munkar, (2) Makna Etis Amar Makruf Nahi Munkar dalam Bernegara, (3) Amar Makruf Nahi Munkar Sebagai Konsekuensi Berdemokrasi, dan (4) Implementasi Prinsip Amar Makruf Nahi Munkar Sebagai Etika Politik Islam.

\section{Pembahasan}

\section{a. Telaah Singkat Prinsip Amar Makruf Nahi Munkar}

Amar Makruf Nahi Munkar secara sederhana berarti menyeru kepada kebaikan dan mencegah keburukan. ${ }^{9}$ Prinsip ini bukan

${ }_{9}$ Dalam bahasa Arab, kata al-amr dapat berarti perintah atau seruan, dan al-ma'rūf dapat berarti sesuatu yang baik atau dikenal. Kalau dua kata tersebut digandengkan maka ia menjadi terma keagamaan yang berarti menyeru kepada kebaikan. Sedangkan al-nahy berarti larangan atau pencegahan, dan al-munkar 
hanya dikenal dalam agama Islam saja, melainkan ia adalah prinsip universal yang ada dalam semua agama. Tak ada ulama baik dari zaman klasik maupun kontemporer yang berbeda pendapat bahwa Amar Makruf Nahi Munkar adalah salah satu asas agama dan kewajiban yang telah diperintahkan oleh Allah. ${ }^{10}$

Hal tersebut demikian karena prinsip Amar Makruf Nahi Munkar telah dengan sangat lugas dijelaskan dalam Alquran di berbagai ayatnya, baik dalam bentuk penyifatan (pujian) terhadap umat Muslim maupun dalam bentuk perintah langsung. Di antara ayat-perintah dalam hal ini adalah sebagai berikut:

Dan hendaklah ada di antara kamu segolongan umat yang menyeru kepada kebajikan, menyeru kepada kebaikan dan mencegah kemunkaran (ya'murūna bi al-ma'rūf wa yanhauna 'an al-munkar); merekalah orang-orang yang beruntung. ${ }^{11}$

Dalam ayat lainnya, Amar Makruf Nahi Munkar digambarkan sebagai sifat dan ciri utama umat Muslim dan sekaligus sebagai alasan mereka digelari sebagai umat terbaik (khaira ummah). Hal ini dapat dipahami sebab dengan terlaksananya prinsip terse-

berarti kemungkaran dan keburukan. Dan kalau dua kata terakhir tersebut digabung maka ia juga menjadi terma keagamaan yang berarti mencegah keburukan. Gabungan dari kedua terma di atas (yakni al-Amr bi al-Ma'rūf wa alNahy 'an al-Munkar) adalah terma lengkap yang merupakan prinsip dan salah satu fondasi tegaknya Islam yang berarti menyeru kepada kebaikan dan mencegah keburukan. Yang termasuk kebaikan (al-Ma'rūf) dalam hal ini adalah segala jenis kebaikan sebagaimana diperintahkan Allah, dan keburukan (al-Munkar) dalam hal ini adalah segala jenis keburukan sebagaimana dilarang oleh Allah. Lihat Majma' al-Lughah al-'Arabiyyah Jumhuriyyah Mishr al-'Arabiyyah, al-Mu'jam al-Wasith, (Kairo: Maktabah al-Syuruq al-Dauliyyah, 2011), hlm. 26, 617, 991, dan 1000.

${ }^{10}$ Lajnah Jurusan Dakwah dan Kebudayaan Islam Universitas al-Azhar, Adhwa' 'ala al-Nuzhum al-Islamiyyah, (tanpa keterangan), hlm. 250.

${ }^{11}$ QS. Ali Imran: 104. 
but dalam suatu masyarakat (dalam hal ini masyarakat Muslim), maka otomatis tiap individu Muslim akan terus saling menasihati dan saling menebarkan kebaikan dan nilai-nilai kemanusiaan sehingga pada akhirnya akan membuat masyarakat Muslim menjadi masyarakat yang kokoh.

Kamu (umat Islam) adalah umat terbaik (khaira ummah) yang dilahirkan untuk manusia, (karena kamu) menyeru kepada kebaikan dan mencegah kemungkaran (ta'murūna bi al-ma'rūf wa tanhauna 'an al-munkar), dan beriman kepada Allah. Sekiranya Ahli Kitab beriman, tentulah itu lebih baik bagi mereka. Sebagian di antara mereka ada orang-orang yang beriman, namun kebanyakan mereka adalah orang-orang fasik. ${ }^{12}$

Sedemikian pentingnya prinsip Amar Makruf Nahi Munkar, hukumnya bahkan sama dengan berperang melawan musuh di jalan Allah, yaitu fardu kifayah. Jadi di antara masyarakat Muslim wajib menunaikan kewajiban ini dengan baik, dan jika tidak maka seluruh masyarakat akan berdosa. ${ }^{13}$ Selain mendapat dosa kolektif, masyarakat Muslim juga akan lebih berpotensi menjadi masyarakat yang bobrok sebab ketiadaan suatu prinsip perekat antara mereka.

Dilihat dari sudut pandang yang lain, Amar Makruf Nahi Mungkar juga dapat dikategorikan sebagai ibadah yang berperan sebagai sarana pendekatan diri pada Allah. Ibadah yang dimaksud di sini adalah ibadah dalam maknanya yang luas. Dalam makna ini, ibadah mencakup keseluruhan kegiatan manusia dalam hidup di dunia ini, termasuk kegiatan duniawi sehari-hari, jika kegiatan itu

${ }^{12}$ QS. Ali Imran: 110.

${ }^{13}$ Ibnu Taimiyah, al-Amr bi al-Ma'ruf wa al-Nahy 'an al-Munkar, (Beirut: Dar al-Kitab al-Jadid, 1976), hlm. 15. 
dilakukan dengan niat pengabdian dan penghambaan diri kepada Allah, yakni sebagai tindakan moral. ${ }^{14}$ Dalam hal ini Amar Makruf Nahi Munkar adalah ibadah sosial ('ibādah ijtimā'iyyah) yang berada di samping ibadah murni ('ibädah mahdhah) seperti salat dan zakat, yang keduanya sama-sama diperintahkan oleh Allah.

Namun hal yang perlu digarisbawahi adalah, bahwa Amar Makruf Nahi Munkar perlu diimplementasikan dengan cara yang ramah. Mengenai hal ini Ibnu Taimiyah menjelaskan bahwa penegakan prinsip ini seyogianya dengan memerhatikan sikap yang lemah lembut (al-rifq). "Sebab itu dikatakan: 'Amar Makruf-mu seharusnya dilakukan dengan makruf, dan Nahi Munkar-mu seharusnya dilakukan tidak dengan munkar'."15

Prinsip Amar Makruf Nahi Munkar juga tentu saja telah dipraktikkan oleh Nabi Muhammad dan para nabi sebelumnya, sebab dengan tujuan itulah mereka semua diutus oleh Allah kepada manusia. Istilah-istilah seperti al-basyīr (pemberi kabar bahagia), al-nadzïr (pemberi peringatan), dan istilah-istilah sejenisnya adalah representasi dari tugas Nabi dalam mengimplementasikan prinsip Amar Makruf Nahi Munkar. ${ }^{16}$ Dengan prinsip inilah Nabi Muhammad dan para nabi sebelumnya berdakwah agar dapat dicamkan oleh masyarakat, sehingga ia akan menjadi prinsip dan fundamen dalam membentuk suatu masyarakat yang religius sekaligus aktif dan partisipatif.

${ }^{14}$ Nurcholish Madjid, Islam Doktrin dan Peradaban, (Jakarta Selatan: Paramadina, 2008), hlm. 57.

${ }^{15}$ Ibnu Taimiyah, op.cit., hlm. 17.

${ }^{16}$ Lihat misalnya QS. Al-Ahzab: 45. 
Menurut Ibnu Taimiyah, praktik Amar Makruf Nahi Munkar dapat melalui tiga cara, yakni dengan hati (al-qalb), lisan (al-lisān), maupun kekuasaan (al-yad). ${ }^{17}$ Ini sesuai dengan sabda Nabi $\mathrm{Mu}-$ hammad bahwa "siapa saja di antara kalian yang melihat kemungkaran maka ubahlah ia dengan kekuasaannya, kalau ia tak mampu maka dengan lisannya, kalau ia masih tak mampu maka [cukup] dengan hatinya." 18 Hal ini sebetulnya menggambarkan keluasan sarana yang dapat digunakan dalam menjalankan prinsip Amar Makruf Nahi Munkar, yakni boleh melalui kekuasaan seperti pemerintah maupun melalui nasihat-nasihat secara verbal maupun melalui tulisan.

\section{b. Makna Etis Amar Makruf Nahi Munkar dalam Bernegara}

Prinsip Amar Makruf Nahi Munkar jika diterjemahkan dalam ruang politik maka ia akan menjadi sebuah etika praktis yang akan merekatkan dan menguatkan suatu negara. Etika tersebut dapat dilihat dari dua sudut pandang: (1) pemerintah, yakni dalam usahanya merumuskan undang-undang demi kemaslahatan negara, dan (2) masyarakat sipil, yakni dalam usaha mereka memberi aspirasi, gagasan, dan kritik kepada pemerintah dan kepada sesama masyarakat. Kedua model ini, baik yang top-down dan bottom-up,

${ }^{17}$ Ibnu Taimiyah, op.cit., hlm. 16.

18 Redaksi Arabnya sebagai berikut:

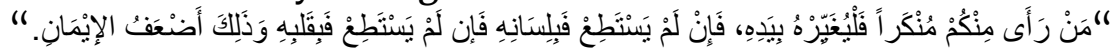

Lihat Muhyiddin bin Syaraf al-Nawawi, op.cit., hadis no. 49. 
akan terus memberikan timbal balik yang produktif sehingga negara dapat mencapai tujuan yang dicita-citakan bersama. ${ }^{19}$

Amar Makruf Nahi Munkar sebagai etika politik juga akan berperan sebagai katalisator dalam pembentukan masyarakat madani dalam suatu negara. Masyarakat madani ini adalah masyarakat yang beradab dan menjunjung tinggi nilai kebersamaan dan kebaikan kolektif. Walaupun masyarakat madani terkesan modern karena demokrasi (yang merupakan awal dari lahirnya konsep masyarakat madani) baru muncul pada zaman modern, namun secara praktis sebenarnya sudah ada sejak zaman Nabi $\mathrm{Mu}-$ hammad di Madinah dulu. Robert N. Bellah, sebagaimana dikutip Nurcholish Madjid, menilai bahwa masyarakat Madinah dulu adalah modern jika dilihat dari tingginya tingkat komitmen, keterlibatan dan partisipasi seluruh jenjang masyarakat. ${ }^{20}$

Masyarakat di Madinah, dengan segala partisipasi politik dan komitmen kebangsaannya, tak dapat dimungkiri dilandasi oleh prinsip Amar Makruf Nahi Munkar. Dan selepas kepemimpinan Nabi Muhammad pun, para khalifah sesudah beliau tetap memegang teguh etika politik tersebut. Karena itu tak jarang para khalifah

19 Mengenai apakah individu yang lebih penting sedang masyarakat adalah instrumen yang diperlukan di dalam penciptaannya atau sebaliknya, menurut Fazlur Rahman, itu hanya merupakan sebuah masalah akademis, karena individu dan masyarakat sejatinya tidak dapat dipisahkan. Hal yang pasti dan tak dapat diragukan adalah bahwa tujuan utama Islam adalah menegakkan sebuah tata masyarakat yang adil, berdasarkan etika, dan dapat bertahan di muka bumi. Lihat Fazlur Rahman, Tema Pokok al-Qur'an, (Bandung: Pustaka, 1996), hlm. 54 .

20 Nurcholish Madjid, "Mewujudkan Masyarakat Madani di Era Reformasi", Titik-Temu, vol. 1, no. 2, Januari-Juni 2009, hlm. 17. 
mendapat beberapa kritik konstruktif dari masyarakat, sebagaimana masyarakat juga mendapat beberapa aturan yang harus ditaati dari pemerintah.

Contoh paling masyhur kritik pemerintah kepada masyarakat (top-down) di zaman khalifah Abu Bakar adalah, ketika pemerintah memerangi orang-orang yang enggan membayar zakat. ${ }^{21}$ Oknum yang enggan membayar zakat akan merusak keimanan mereka sendiri sebab menunaikan zakat adalah salah satu rukun Islam yang wajib dilaksanakan, dan selain itu tidak membayar zakat sama saja dengan merusak ekonomi negara dengan sengaja, anggaran dananya otomatis akan menurun drastis disebabkan berkurangnya kesadaran masyarakat akan pentingnya zakat (atau pajak).

Adapun contoh kritik masyarakat terhadap pemerintah (bottom-up) pada zaman khalifah Umar bin al-Khaththab adalah perihal mahar yang direncanakan akan ditetapkan batas maksimal tertentu. Hal tersebut, yang termasuk dalam urusan hukum pernikahan dan keluarga, dikritik oleh seorang perempuan karena dinilai tidak perlu dan terlalu membatasi. Lalu pada akhirnya Umar bin al-Khaththab menyetujui sang perempuan seraya berkata, "bahkan perempuan pun lebih tahu daripada Umar." 22

Hubungan timbal balik antara masyarakat dengan pemerintah sebagaimana disebutkan di atas adalah representasi dari prinsip Amar Makruf Nahi Munkar. Berdiskusi dan berdebat

${ }^{21}$ Lihat Muhyiddin bin Syaraf, op.cit., hadis no. 20.

${ }^{22}$ Kamal Basyuni, Qa'id al-Fikr al-Islami: Umar bin al-Khaththab, jilid 4 (Kairo: Maktabah al-Nahdhah al-Mishriyyah, 1993), hlm. 27. 
dengan baik pun juga adalah salah satu bentuk dari prinsip tersebut, terlebih dalam masyarakat yang demokratis. Tidak sedikit riwayat yang menyebutkan bahwa Nabi Muhammad dan para khalifah setelah beliau sering melakukan perundingan, bahkan sampai tahap perdebatan yang menegangkan (namun tetap saling menghormati). ${ }^{23}$ Hal ini adalah legal dan memiliki legitimasinya sendiri dalam Alquran, yaitu ayat-ayat tentang anjuran bermusyawarah (seperti QS. Ali Imran ayat 159 dan QS. Al-Syura ayat 38).

\section{c. Amar Makruf Nahi Munkar ; Konsekuensi Berdemokrasi}

Dalam negara yang menerapkan sistem demokrasi, ada beberapa hal yang menjadi konsekuensi yang tak terhindarkan akan terjadi, seperti maraknya perdebatan dan perseteruan pemikiran antar masyarakat dan/atau antara masyarakat dan pemerintah. Namun demikian, "demokrasi tetap merupakan sistem politik yang lebih sedikit mudaratnya dibandingkan sistem-sistem politik lain semacam monarki, teokrasi, atau oligarki." ${ }^{24}$

Dalam demokrasi, semua warga negara berhak mengeluarkan pendapat serta kritik baik kepada sesama masyarakat maupun

${ }^{23}$ Contoh menarik mengenai hal ini adalah kisah khalifah Umar bin alKhaththab ketika mendapati permasalahan pembagian tanah hasil rampasan perang. Ia ingin mengubah ketentuan awal bahwa para prajurit yang biasa mendapat 4/5 dari hasil keseluruhan diubah dengan konsep baru yang lebih mengutamakan kemaslahatan umum (tidak 4/5 lagi). Hal ini pada awalnya mendapatkan respons yang negatif dari para Sahabat, namun kemudian usulan khalifah Umar tersebut diterima semua pihak dan menjadi aturan resmi. Lihat Kamal Basyuni, Qa'id al-Fikr al-Islami: Umar bin al-Khaththab, jilid 5 (Kairo: Maktabah al-Nahdhah al-Mishriyyah, 1993), hlm. 47-53.

${ }^{24}$ Azyumardi Azra, Transformasi Politik Islam; Radikalisme, Khilafatisme, dan Demokrasi, (Jakarta: Prenadamedia Grup, 2017), hlm. 277. 
kepada pemerintah. Pada akhir abad ke-19, sebagai akibat dari pergolakan sistem politik monarki, gagasan mengenai demokrasi mendapat wujud yang konkret sebagai sistem politik yang menganut kebebasan individu, kesamaan hak, serta hak pilih untuk semua warga negara. ${ }^{25}$

Sistem demokrasi ini muncul dengan membawa teori rasionalistis yang umumnya dikenal sebagai Kontrak Sosial (Social Contract, al-Ta'äqud al-Ijtimā'î). Teori ini beranggapan bahwa hubungan antara pemerintah dan masyarakat didasari oleh suatu kontrak yang ketentuan-ketentuannya mengikat kedua belah pihak. Di satu pihak pemerintah diberi wewenang untuk menyelenggarakan penertiban, dan di pihak lain, masyarakat akan menaati pemerintah asal hak-hak dasar mereka terjamin. ${ }^{26}$

Dalam sistem ini, pergolakan ide akan senantiasa berlangsung sepanjang keran kebebasan berekspresi masih dibuka. Hal yang dibutuhkan tentunya adalah sikap toleransi dan mawas diri yang tinggi. Dalam kaitannya dengan hal ini, Ahmad Syafii Maarif berkata:

Gesekan pendapat jika didialogkan secara dewasa akan melahirkan rumusan pandangan yang lebih kuat dan komprehensif. Orang tidak boleh merasa selalu berada di pihak yang paling benar, sebelum pendapatnya itu diuji melalui dialog yang sehat dalam suasana toleransi dan terbuka. ${ }^{27}$

${ }^{25}$ Miriam Budiardjo, Dasar-dasar Ilmu Politik, (Gramedia Pustaka Utama, 2017), hlm. 111-112.

${ }^{26}$ Ibid., hlm. 111.

27 Ahmad Syafii Maarif, Islam dalam Bingkai Keindonesiaan dan Kemanusiaan, (Bandung: Mizan, 2015), hlm. 189. 
Demokrasi sebagai sistem pemerintahan yang mengharuskan adanya perdebatan ide dengan cara dialog yang ramah dan toleran adalah juga representasi dari prinsip Amar Makruf Nahi Munkar. Tanpa sistem ini, tak akan ada legalitas untuk berbeda pendapat dan untuk berdialog, sehingga kegiatan menyeru pada kebaikan dan mencegah keburukan akan tersendat. Dan pada akhirnya negara akan menjadi eksklusif karena tidak ada toleransi yang dipupuk, dan akan mati karena tidak ada ide yang dapat hidup.

Demokrasi dengan prinsip Amar Makruf Nahi Munkar adalah dua hal yang berbeda namun memiliki kaitan yang sangat erat sehingga sudah sewajarnya ada dalam satu negara. Demokrasi sebagai sistem akan membuat suatu negara memiliki potensi yang luas untuk bersuara dan berdakwah, sedangkan prinsip Amar Makruf Nahi Munkar adalah kegiatan pengimplementasian potensi tersebut dalam ranah praktis.

Demokrasi memungkinkan masyarakat untuk mendapatkan hak dan menjalankan kewajiban secara lebih bebas. Dalam praktiknya, demokrasi tidak selalu berjalan dengan sempurna walaupun telah menjadi sistem pemerintahan hampir seluruh negara di dunia. Namun demikian ia tetap menjadi sistem yang lebih egaliter dan membuka peluang masyarakat untuk berekspresi (dan berdakwah) dalam rangka meningkatkan kualitas bangsa. ${ }^{28}$ Potensi ini akan semakin mudah dicapai dengan adanya katalisator berupa nilai-nilai atau prinsip-prinsip dalam praktik berpolitik. Dalam hal

${ }^{28}$ Lihat Ahmad Syafii Maarif, ibid. Lihat juga Azyumardi Azra, op.cit. 
ini, prinsip Amar Makruf Nahi Munkar adalah salah satu prinsip yang ditawarkan oleh Islam dalam bermuamalah antar manusia dari berbagai aspeknya.

\section{d. Implementasi Prinsip Amar Makruf Nahi Munkar Sebagai Etika Politik Islam}

Etika politik Islam mencakup nilai-nilai universal yang termaktub baik secara eksplisit maupun implisit dalam Alquran dan Hadis, seperti nilai keberanian mengemukakan kebenaran, kesabaran dalam mengakui kesalahan, dan toleransi dalam menghadapi perbedaan pendapat dan gagasan. Semua nilai-nilai tersebut adalah turunan dari suatu prinsip utama Amar Makruf Nahi Munkar. Dalam prinsip ini tiap warga negara akan berhubungan dengan aktif dan mutual, saling memberikan masukan demi kemaslahatan bersama.

Dalam Alquran, terdapat satu ayat sentral mengenai etika sosial-politik Islam yang merupakan prinsip terbentuknya masyarakat Muslim yang berkeadaban, yaitu sebagai berikut:

"Orang-orang yang beriman, laki-laki dan perempuan, sebagian dari mereka menjadi penolong bagi sebagian yang lain. Mereka menyuruh kepada yang makruf dan mencegah dari yang mungkar (ya'murūna bi al-ma'rūf wa yanhauna 'an al-munkar), menegakkan shalat, menunaikan zakat, serta taat kepada Allah dan Rasul-Nya. Mereka itu akan diberi rahmat oleh Allah. Sesungguhnya Allah Mahaperkasa lagi Mahabijaksana." 29

Seakan menguatkan makna surat Ali Imran ayat 110 yang dikutip sebelumnya, ayat ini menggambarkan bahwa ciri utama

${ }^{29}$ QS. Al-Taubah: 71.

124| $\begin{aligned} & \text { Badrul Jihad } \\ & \text { Implementasi Prinsip Amar Makruf... }\end{aligned}$ 
masyarakat Muslim adalah saling tolong menolong dan menjalankan Amar Makruf Nahi Munkar, selain menegakkan salat dan menunaikan zakat. Ayat ini bersama ayat-ayat lainnya menjadi pedoman bagi para individu-individu Muslim dalam membentuk masyarakat kuat dan berkeadaban.

Menurut Bayyumi, ada beberapa nilai yang telah diajarkan oleh Islam dalam bernegara namun jarang disadari, yang pada dasarnya semua itu berada dalam prinsip Amar Makruf Nahi Munkar, di antaranya: pluralisme dan dialog (al-ta'addudiyyah wa al-hiwar), kritik pemerintah (muhasabah al-sulthah), kewarganegaraan (almuawathanah), dan sebagainya. ${ }^{30}$ Semua nilai-nilai tersebut adalah bagian-bagian penting dari prinsip utama yang harus saling menguatkan satu sama lain, sebagaimana nilai-nilai tersebut juga bersifat dinamis sesuai dengan kondisi masyarakat yang juga dinamis.

Pada akhirnya, manusia tak dapat hidup sendiri karena ia merupakan makhluk sosial. Dalam kehidupan sosial tersebut, manusia membentuk suatu pemerintahan yang bertujuan untuk membentuk suatu masyarakat yang abadi dalam keadaan hak-hak para warga negara terpenuhi. Sebagai makhluk sosial-politik, manusia dituntut untuk tetap memegang teguh prinsip Amar Makruf Nahi Munkar. "Jika berkumpul dua orang atau lebih maka sudah sewajarnya mereka saling ber-Amar Makruf Nahi Munkar. Itulah sebabnya kenapa salat jamaah harus terdiri dari minimal dua

30 Abd al-Mu'thi Muhammad Bayyumi, al-Islam wa al-Daulah alMadaniyyah, (Kairo: al-Hai'ah al-Mishriyyah al-'Ammah li al-Kitab, 2019). 
orang, yang satu [berperan] sebagai imam dan yang lainnya [berperan] sebagai makmum." 31

Secara konkret, implementasi prinsip Amar Makruf Nahi Munkar dalam sebuah negara di antaranya adalah sebagai berikut:

a. Rapat dalam merumuskan undang-undang oleh Dewan Perwakilan Rakyat (DPR). Para anggota dewan dipilih oleh rakyat untuk mengemban tugas membuat dan menguji undang-undang yang nantinya akan diterapkan pada masyarakat. Karena itu dalam perumusannya akan dilakukan dengan melalui rapat yang panjang dan beberapa kali uji materi. Perdebatan yang terjadi dalam rapat ini merupakan contoh dari proses Amar Makruf Nahi Munkar, artinya di dalam rapat akan terjadi demonstrasi antar gagasan yang sama-sama dianggap baik (makruf), dan pada akhirnya nanti akan terpilih gagasan dengan suara terbanyak yang diharapkan akan paling sesuai dengan maslahat masyarakat.

b. Patroli polisi dalam mengamankan lalu lintas dan pengawalan demonstrasi serta kerusuhan-kerusuhan yang terjadi. Polisi tak dapat diragukan lagi adalah tangan pemerintah dalam menertibkan masyarakat. Patroli ini adalah bentuk Amar Makruf Nahi Munkar di mana, misalnya, keamanan lalu lintas adalah hal yang makruf sedangkan melanggar aturan lalu lintas adalah hal yang munkar. Begitu juga dalam hal pengawalan ketika ter-

${ }^{31}$ Ibnu Taimiyah, op.cit., hlm. 66. 
jadinya demonstrasi dan pengamanan ketika terjadi kerusuhan, juga merupakan usaha dalam meminimalisir perbuatan-perbuatan anarkis dan tindakan buruk lainnya (munkar).

c. Kegiatan-kegiatan ormas-ormas dan LSM-LSM dalam memberikan pelayanan bagi masyarakat maupun kritik terhadap pemerintah. Hal ini adalah konsekuensi logis dari diterapkannya sistem demokrasi, yakni memungkinkan adanya masyarakat yang saling membantu dalam kebaikan dan memberi aspirasi kepada pemerintah dalam kaitannya dengan kebijakan yang akan atau sedang dirumuskan. Ormas dan LSM di sini bergerak ke dua arah, yakni (1) sesama masyarakat, yaitu dalam upaya mereka mengembangkan masyarakat dalam bidang pendidikan, sosial, dan ekonomi, yang juga merupakan concern pemerintah; juga (1) kepada pemerintah, sebagai penyalur kritik konstruktif dan aspirasi dari masyarakat. Tak diragukan lagi bahwa membimbing masyarakat dan menyalurkan kritik kepada pemerintah adalah bentuk konkret dari prinsip Amar Makruf Nahi Munkar.

\section{D.Penutup}

Amar Makruf Nahi Munkar adalah prinsip dasar dalam Islam yang mencakup berbagai aspek kehidupan. Dalam aspek politik, Amar Makruf Nahi Munkar dapat diimplementasikan sebagai etika 
berbangsa dan bernegara baik oleh pemerintah maupun masyarakat. Prinsip ini akan mengantarkan pelakunya pada sikap yang aktif-partisipatif dalam menebarkan kebaikan demi kemaslahatan bersama. Bentuk pengimplementasian prinsip ini pun beragam, dapat berupa kritik masyarakat kepada pemerintah tentang suatu rancangan undang-undang (RUU), kritik antar masyarakat tentang urgensitas pengembangan ekonomi negara, kritik pemerintah terhadap masyarakat dalam praktik undang-undang atau kebijakan yang ada, dan bentuk-bentuk lainnya yang tak terbatas.

Secara normatif Islam telah mengajarkan prinsip Amar Makruf Nahi Munkar di berbagai ayat Alquran dan praktik Nabi Muhammad sendiri. Pada masa kini, terlebih di negara-negara dengan sistem pemerintahan yang demokratis, prinsip ini perlu diimplementasikan sebagai etika politik yang akan memandu langkah negara-negara tersebut pada kekuatan dan keadaban yang dicita-citakan.

\section{DAFTAR PUSTAKA}

Al-Nawawi, Muhyiddin bin Syaraf. 2016. Shahih Muslim bi Syarh alNawawi. Kairo: Syarikah al-Quds.

Azra, Azyumardi. 2017. Transformasi Politik Islam; Radikalisme, Khilafatisme, dan Demokrasi. Jakarta: Prenadamedia Grup.

Basyuni, Kamal. 1993. Qa'id al-Fikr al-Islami: Umar bin alKhaththab. Kairo: Maktabah al-Nahdhah al-Mishriyyah. 
Bayyumi, Abd al-Mu'thi Muhammad. 2019. Al-Islam wa al-Daulah al-Madaniyyah. Kairo: Al-Hai'ah al-Mishriyyah al-'Ammah li al-Kitab.

Budiardjo, Miriam. 2017. Dasar-dasar Ilmu Politik. Gramedia Pustaka Utama.

Handoyo, Eko, dkk. 2016. Etika Politik. Semarang: Widya Karya Press.

Ibnu-Taimiyah. 1976. Al-Amr bi al-Ma'ruf wa al-Nahy 'an alMunkar. Beirut: Dar al-Kitab al-Jadid.

Lajnah Jurusan Dakwah dan Kebudayaan Islam Universitas alAzhar. Adhwa' 'ala al-Nuzhum al-Islamiyyah.

Maarif, Ahmad Syafii. "Sistem Khilafah dalam Tradisi Islam". Titik-Temu. Vol. 1, No. 2. Januari-Juni 2009. . 2015. Islam dalam Bingkai Keindonesiaan dan Kemanusiaan. Bandung: Mizan.

Majma' al-Lughah al-'Arabiyyah Jumhuriyyah Mishr al'Arabiyyah. 2011. Mu'jam al-Wasith. Kairo: Maktabah al-Syuruq al-Dauliyyah.

Madjid, Nurcholish. 2008. Islam; Doktrin dan Peradaban. Jakarta Selatan: Paramadina. . "Menciptakan Masyarakat Madani di Era Reformasi". Titik-Temu, vol. 1, no. 2, Januari-Juni 2009. 